\author{
Review Article \\ www.ijrap.net
}

\title{
DALHANA AND HIS CONTRIBUTION IN DRAVYAGUNA \\ WITH SPECIAL REFERENCE TO FUNDAMENTALS
}

Sharma Tarun ${ }^{1 *}$, Ramamurthy A. ${ }^{2}$, Sharma Ravindra ${ }^{3}$, Malviya Reeta ${ }^{4}$

${ }^{1}$ P.G. Scholar, Department of P.G. Studies in Dravyaguna, National Institute of Ayurveda, Jaipur, Rajasthan, India

${ }^{2}$ Asst. Professor, Department of P.G. Studies in Dravyaguna, National Institute of Ayurveda, Jaipur, Rajasthan, India

${ }^{3} \mathrm{Ph}$.D. Scholar, Department of P.G. Studies in Dravyaguna, National Institute of Ayurveda, Jaipur, Rajasthan, India

${ }^{4}$ Assistant Professor, Department of Dravyaguna, Mahatma Jyotiba Fule Ayurveda College, Chomu, Jaipur, Rajasthan, India

Received on: 07/04/16 Revised on: 24/05/16 Accepted on: 08/06/16

\author{
*Corresponding author \\ E-mail: tarunsharma1286@gmail.com
}

DOI: 10.7897/2277-4343.074124

\begin{abstract}
In Samhitas the facts have been presented in Sutra form and in commentaries the same have been interpreted and elaborated in form of Bhasya. Thus the commentaries serve the purpose of Bhasya on the Samhitas which not only give meaning of words but also supplement the ideas by furnishing additional information on the subject. The commentator quotes the previous work and after critical verification gives his own conclusion based on either rejection or agreement on logical grounds. Dalhana commentary on Sushruta Samhita is Nibandha Sangraha. No other work than the commentary on Sushruta Samhita is known to the credit of Dalhana. It shows that he devoted his whole life in studying the earlier Samhitas and previous commentaries on the Sushruta Samhita and finally in giving shape to his commentary. Apart from study, he also devoted much time in field study which is shown by his casual observation in the field of Dravyaguna by mentioning the characters and local names of plants and also the regional traditions. Along with Dalhana has made notable contribution in the field of basic concepts of Dravyaguna. He has interpreted the Sushruta's view faithfully in the field of basic concepts of Dravyaguna (like Rasa, Guna, Virya, Vipaka, Prabhava and Karma). The aim of this paper is to put forward the valuable contribution of Dalhana in the field of Dravyaguna fundamentals.
\end{abstract}

Keywords: Commentary, Dalhana, Sushruta Samhita, Dravyaguna fundamentals.

\section{INTRODUCTION}

Dalhana, the celebrated commentator of the Sushruta Samhita, and the author of 'Nibandha Sangraha' is one of the ancient luminaries of the Indian system of medicine. Dalhana wrote his commentary on Sushruta Samhita and the commentary name is Nibandha Sangraha. Not only this, no work other than this commentary ascribed to him. It shows that he devoted his whole life in studying the earlier Samhitas, various aspects of previous commentaries on the Sushruta Samhita and devoted much time in field study. Dalhana, in his commentary, has given clearly information about his place, genealogy and patron ${ }^{1}$.

Accordingly Dalhana Belonged to a place named Ankola near Mathura in Bhadanaka Region where mostly Vaidyas lived. The place has not been identified but the word 'Bayana' might be a derived form of Bhadanaka and now 'Bayana' is situated in Bharatapur district in Rajasthan state. He belonged to a family of Sauravansiya Brahmanas. He has mentioned his father's name but has not given his mother's name. His father's name was Bharatapala ${ }^{2}$.

In my opinion Bhaskara, the author of Panjika was teacher of Dalhana who has been referred to by the epithets 'Guru', 'Acharya' and also by his work 'Panjika'. It is also to be noted that the Dalhana has followed totally the views of Panjika and has not gone against it ${ }^{3}$. Dalhana consulted Nyayachandrika of Gayadasa and Panjika of Bhaskara among other work while composing the commentary.
The Kala (period) of Dalhana is Last quarter of the 12th cent. $\mathrm{AD}$. The important clue for the date of Dalhana is his intimate association with a king, Sahajapaladeva or sahala ${ }^{1}$ The date of Sahajapaladeva is the last quarter of 12th cent. AD. Dalhana quotes Chakarapanidatta ${ }^{4}(11$ cent. AD) and is quoted by Hemadri (13 cent. AD). Hence His date may be fixed conveniently in the Last Quarter of the 12th Cent.AD.

After going through the entire commentary one can easily find that Dalhana was a great scholar of Ayurveda and he studied all available Samhitas on different specialities of Ayurveda. Apart from Ayurveda, Dalhana was also well-versed in several other branches of learning like Sruti, Smriti, Vyakarana, Darshana, Jyotisha, Tantra, Aswashastra, Gajashastra etc. He has referred to these disciplines as 'Paratantra' ${ }^{5}$ ' Anya Shastra' ${ }^{6}$.

Paratantara- In Dalhana opinion Paratantara means the Ayurvedic text dealing with the specialities other than the Sushruta Samhita.

Anya Shastra- In Dalhana opinion Anya Shastra means other branches of learning some take it as other specialities of Ayurveda itself.

Dalhana has always recourse to his own critical study and that is why he said himself as 'Viveka-Brhaspati' (Great in the discriminating faculty). Because of the rich tradition, long experience and independent judgement Dalhana has been able to contribute original ideas in several fields of Indian Medicine and owing to this he stands foremost among the commentators. 


\section{Dalhana's Contribution}

Dalhana has made notable contributions in the field of Dravyaguna which may be summarize as follows.

- He has interpreted the Sushruta's view faithfully in the field of basic concepts of Dravyaguna like Rasa, Guna, Virya, Vipaka and Prabhava and Karma.

- He described the morphological characters of drugs which are not found in Nighantus and by which the Drugs can be identified easily. These drugs are Vatama (Prunus amygdalus Batsch.), Akshoda (Juglans regia Linn.) etc.

"Akshodomadanaphalaakarphalomadhyekinchidunnatarekhanvi taparvatapilu Akhrota iti loke.,"7

- He has given popular names (Lok Prasiddha) of the plants and drugs for easily identification. These names can be distinguished in two categories- one the Sanskrit names popular in learned circle and the other local names prevalently used by the common man such as Falsa for Parushaka (Grewia asiatica Linn.), (Alsi ${ }^{8}$ for Atasi (Linum usitatissimum Linn.), Poi ${ }^{9}$ for Upodika (Basella rubra Linn.) etc.

"Parushakoalpaasthimriduphala Faalsa iti loke.",10

- He has mentioned the popular use of plants and drugs prevalent in various regions and also preparation and mode of administration (part used, dosage, vehicle etc.) of the same.

- He has also mentioned some new synonyms for plant names such as Kantakika ${ }^{11}$ or Katayika for Vikankata (Flacourtia ramontchi $\mathrm{L}$. Herit).

- He has mentioned the habitat of plants in a no. of cases due to sufficient field study and observed plants in various regions such as Pilu ${ }^{12}$ (Salvadora persica Linn.) in Bhadnaka region.

\section{Basic concepts of Dravyaguna}

\section{Dravya}

Acharya Charaka and Sushruta have given the definition Dravyas as, the substance, where in exist the properties and actions in an inseperable relationship is called Dravya ${ }^{13,14}$. The properties (Guna) and actions (Karma) have no identity or existence without the substance and the substance has no recognition without the Guna and Karma. This coexistence of Dravya, Guna and Karma is known as samavaya.

Dalhana says - "Dravyamaushadhamucchyate."15

Dalhana says that where karma (action) and Gunas (properties) are situated and which is Samavayi Karana (material cause) is termed as Dravya. Only Dravya is Samavayi karana just as thread in piece of cloth, clay particular in a pitcher etc. ${ }^{14}$ Dravya is Ashraya (substratum) and the Gunas, Rasa etc. are Ashrayi (dependent). In fact, the emergence of both Ashraya and Ashrayi is simultaneous and as such they are interdependent.

Dravya stays for a certain period and not Rasa etc. For example, the Mango fruit (Mangifera indica Linn.) at first in KashayaAmla, then Amla and finally becomes Madhura but still it always remains as Mango fruit and does not change into the fruit of Amrataka (Spondias mangifera Willd.) or Koshamra (Schleichera trijuga Willd.). The word 'Nitya' in this context, has been interpreted rightly as one remaining for a certain period and Anitya which is destroyed even with this period ${ }^{14}$.

\section{Guna}

Acharya Charaka has explained the word Guna. The Dravya possesses Karma (action), whereas Guna stays in Dravya in the form of nischesta (in a passive or inactive state). This state is called as samavayi sambhandha. Here the Guna is present in an inactive state, which is known as gauna. Therefore this character is known as Guna ${ }^{16}$

"Gunashabdah Karmavachi., 17
"Gunashabdastatkaryephale vartate., 18

According to Dalhana the word 'Guna' is ordinarily used for 'Phala' (result) as well as 'Karma' (action), it denotes properties like Guru-Laghu etc. which are situated in Dravya. Gurvadi Guna:-

Gurvadi Gunas are twenty in number. Sushruta has accepted some more Gunas like Vyavayi, Vikasi, Ashukari, Sugandha and Durgandha in addition to twenty Gurvadi Gunas. According to Dalhana twenty Gurvadi Gunas are-

"Gunahsheetoshnasnigdharukshamandatikshnagurulaghupichhi lavisadaslakshnaparushakathinamridudravasandrasthirasarasth ulasukshmavinshati. ${ }^{, 15}$

Sheeta-Ushna: These are used in the sense of Sparsha (touch) as well as Virya.

Snigdha-Ruksha: Snigdhta means smoothness, Rukshta means roughness.

Guru-Laghu: These terms are used in three contexts- Matra (quantity), Guna (property), and Vipaka (digestion). Laghutva has been interpreted as opposite to Gurutva as property of Aakasha.

Piccchila-Visada: Picchila is uplepi and has mucous touch. Mritsna is a synonym of Picchila. Visada is opposite to Picchila. Visada has been interpreted as Ruksha.

Slakshna-Parusha: In the Sushruta Samhita, Karkasa is in place of Parusha. Slakshna (smoothness) is opposite to Karkasa which is rough in touch like Karkotaka phala (Momordica dioica Roxb.)

Manda-Tikshna and Mridu-Kathina: Generally the pair is Manda-Tikshna and Mridu is a partner of kathina but Sushruta has not accepted Kathina as a separate entity but only a synonym of Sandra and Manda has been read with Sara. Hence in Sushruta's view, Mridu-Tikshna is the pair. Mridu is soft and delicate which does not exert devastating effect. Opposite to Mridu, Tikshna is a property which exerts immediate, strong and painful effect and also vitiates Pitta. Manda is mild which vitiates the Vishama Dosha. Kathina is hard which strengthen the body.

Sandra-Drava: Sandra has been interpreted by the words 'Bahala' (Ghana) and Samhata (compact). Dravatava indicates Tanutva or Acchattva. Drava relieves hunger and thirst.

Sthira-Sara: Sushruta does not accept Sthira Guna separately, but at various places he defines the word Sthira variously such as Kathina (hard), Aviasarpi (that which does not spread) and motionless. Opposite to Sthira, Sara is of spreading nature and Anulomana.

Sthula-Suksma: Regarding Sthula, Dalhana says that Sthula has gross parts like Pistanna etc. Suksma is that which penetrates even the minutest channels.

Vyavayi: Vyavayi is that which first circulates in the whole body and then goes to digestion like Visha (poisons) and Madya (alcoholic beverages) ${ }^{19}$.

Vikasi: By spreading in the body, produces Lassitude including joints $^{20}$.

Ashukari: This is also termed as Ashu or Shighra because of its immediate action. 
Yogavahi: Yogavahi is that which acts like other partner with which it is combined ${ }^{21}$.

\section{Paradi Guna:-}

Acharya Sushruta has not described Paradi Gunas but Dalhana in his commentary has commented upon these terms.

Yukti or Yojana vishesha is defined in which all the relevant factors are considered.

\section{"Yuktivisheshoyojanavisheshah \\ toyaagnisanskarvasnabhavnamatrakaladyapekshah. ${ }^{, 22}$}

Samyoga is combination with one, two, or more drugs.

Vibhaga is disjunction.

Prithktwa $^{23}$ is separateness as Sira, Snayu, Peshi, etc., are mutually separate individually and also as a group.

\section{Rasa}

"Rasomadhuradikah."15

Rasa is interpreted by the synonym Aaswada. Rasas are six in number- Madhura, Amla, Lavana, Katu, Tikta, Kashaya, generally said as Madhuradi.

Regarding Bhautika composition of Rasa, some rasa like Lavana is composed of Jala and Agni which are quite opposite to each other. Dalhana says that opposition is only when they come from different direction but when they are produced together with a single purpose or due to Prabhava, Agni is not subdued by Jala in such cases.

\section{Vipaka:}

According to Acharya Vagbhata Vipaka is that, where in the basic substances or Dravya, by the action of Jatharagni, during the process of digestion, at the end a product will be formed as a special type of Rasa ${ }^{24}$. This Vipaka is also known as Nisthapaka.

"Yaddravyamparinamkaaleswabhavikamrasamparityajyarasant arambhajte tatra Vipaka iti sangya.,"15

Vipaka has been defined as 'Visista Paka'25 (particular transformation) in contrast to 'Paka' (general digestion). Dalhana said that Vipaka is the term used in Relation to a substance which during digestive process accepts another Rasa leaving its natural Rasa.

Sushruta has used the term Vipaka both for digestive and post digestive transformation. He says that Vipaka is important because the effect of the ingested substance depends upon whether it is digested properly or not. Dalhana explaining it further adds that if it is properly digested it would produce beneficial effect (Guna) otherwise Dosha. Dalhana has said two types of Vipaka-Guru and Laghu.

\section{Virya}

According to Acharya Charaka and Sushruta the active property or potency of a Dravya when performed is known as Virya ${ }^{26}$. The term Virya is interpreted as Shakti (potency). It has been said that Virya is the Sara of the drug which is destroyed after a certain period and is accentuated by certain process.

"Dravyarasagunavipakairyata karma kartum na shakyate tat karma kurvan prabhavo viryamuchayate, tathahiviryamshaktirutpattivisheshah, samarthyam prabhava ityanarthantaram. ",15

Dalhana does not distinguish Virya from Prabhava. He has defined Virya (1) As a means of inexplicable action (2) As Prabhava producing action for which Dravya, Rasa, Guna and
Vipaka are incapable and having synonym Shakti, Utpattivisesa, Samarthya and Prabhava. Dalhana has confused the issue by saying Virya as 'Achintya Kriyahetu' ${ }^{27}$ and making Virya and Prabhava as synonymous.

The number of Virya is two according to Sushruta though he has mentioned eight Viryas according to other's view. Dalhana too follow the same. Although there is no third category but Sita and Ushna according to the predominance of Soma and Agni in principle, practically there is accepted a group on borderline which is termed as 'Sadharana ${ }^{28}$ (common or intermediate), example- Kakmachi (Solanum nigram Linn.).

Dalhana has distinguished Agneya from Ushna and clarify it with certain examples such as Prabha (lusture) is Agneya but not Ushna, Kshara is Ushna but not Agneya, Matsyas (fishes) are also Ushna but not Agneya ${ }^{20}$. The examples of Agneya Dravyas are Tila (Sesamum indicum Linn.), Maasha (Phaseolus mungo Linn.), Sura (Liqour) etc.

\section{Prabhava}

Acharya Charaka says that Prabhava is considered as a special power or specific property of substance, because the Dravya having similar Rasa, Virya and Vipaka produce or exhibit special action. This specific action of the Dravya is known as Prabhava ${ }^{29}$.

According to Dalhana, Virya and Prabhava have been mentioned as synonyms but Prabhava can be distinguished by the terms Swabhava, Prakriti or Shaktivisesha ${ }^{30}$. Swabhava is 'Sahaja Dharma' (inherent activity) due to specific natural composition of the drug. Prabhava is actually a Shortened form of Dravya-Prabhava. It is also mentioned as Aadhara Prabhava because Dravya is Aadhara of all the properties. The effect of Mantra-Tantara, anti-poisons, emetics etc., is also due to this Achintya Shakti.

Certain actions of several drugs have been explained by Prabhava such as Samgrahi effect of Ghrita obtained from milk, Pachana effect of Sitavirya Saktu, Vrshya effect of washing the feet etc. The Tridoshaghna effect of drugs like Amalaki (Emblica officinalis Gaertn.), Kakmachi (Solanum nigrum Linn.),Guduchi ${ }^{31}$ (Tinospora cordifolia (Willd.) Miers ex Hook. F. \& Jhoms.) etc., is also explained by Prabhava.

\section{Karma}

Acharya Charaka has given definition of Karma. The Karma or the action is responsible for the act of adhering and separation that is samyoga and vibhaga, of a Dravya, which is intimately associated with and independent in a substance. There cannot be any action without samyoga and vibhaga. The Dravyagata padhartha which produces effects on the body is known as Karma $^{32}$.

According to Dalhana Karma denotes activities of Drugs such as Sodhana etc. Drug Treatment consists of Samsodhana and Samsamana. He also explained the difference between like Vinasana, Harana and Soshana.

Vinashanharanavishoshananaamarthabhedamaahutatrakushthavinashanomulochhedanah, haranomehapandavadehsanshamanatvennirmulanatvenva, shoshanahkaphamedsodravasnigdhyo."33

According to Dalhana interpretation of some certain terms denoting action is given here:

Sukha: That which provide health. ${ }^{34}$

Hladana: That which provide relief by subsiding thirst, sweat, burning sensation etc. ${ }^{35}$

Ashwasajanana: Renovate the persons exhausted by overwork. 
Kshapana: Kshapana is decreasing below the base level. While explaining the Kshapana effect of Doshas on Dhatus, Dalhana says- Pitta decreases Dhatus due to Katu and Ushna properties, Vayu because of absorbing nature and Kapha by causing obstruction in channels. ${ }^{37}$

Sthapna: Which does not produce obesity or leanness but maintains the medium state of body bulk. ${ }^{38}$

Anulomana: Which helps excretion of Vata (flatus), Mutra (urine) and Purish (faeces).

Dharana: Supporting in case of emergency. ${ }^{36}$

Yatrakara: Which maintains the body. ${ }^{39}$

Apyayana: which hastens recovery by replenishing memory, voice, strength and semen etc. ${ }^{40}$

Samshamana: The substance which ingested pacifies Doshas without eliminating it is known as Samshamana (pacificatory) as said- that which does not eliminate Doshas, nor does aggravate the balanced ones but pacifies the aggravated ones is known as Samshamana. This is of two types- external and internal, the former such as Aalepa, Parisheka, Avgahana, Abhayanga, Shirobasti, Kawala, Gandusha etc. while the later such as Pachana, Lekhana, Brihana, Rasayana, Vajikarana, Visha-Prasamana etc.

Samshodhana: Samsodhana is that which purifies well, it is of two types- external and internal. The external such as sharp instrument (Shastra), caustic alkali (Kshara), cautery (Agni), paste (Pralepa) etc. while the internal is of four types-Vamana, Virechana, Asthapana and Raktamokshana.

\section{Rasayana:}

"Rasanam rasayanam.", 41

rasaraktaadinnaamayanamaapyayanam

According to Sushruta, Rasayana is Vayasthapana (maintaining youth), promoting life-span, intellect and strength and eliminating diseases. Interpreting the word Vayasthapana, Dalhana says that it means maintaining life span up to 100 years of age while Ayushkara may go beyond this limit. ${ }^{42}$

Dalhana has classified Rasayana in the following way ${ }^{43}$ :

(1)Kutipraveshika (indoor) (2) Vatatapika (outdoor)

(1)Kamya(specific) (2) Naimittika(curative) (3) Aajasrika (general)

(1)Samshodhana (purifying) (2) Samshamana (pacifying)

\section{Vajikaran}

"Yena strishu vishye vaajivanarahsamarthyam prapnoti tadvaajikaranam, yenatyarthamvyajyate strishu tadvaajikaranam., 44

Vajikarana has been interpreted in both the senses.

(1) Producing semen

(2) Stimulating impulse and sexual potency.

"Tatatrividham-janakam,pravartakam,janakapravartakamcheti. Tatrajanakammasghritaadikam, pravartakamuchhatachurnaadikamshukravairechanikam, janakpravartakamtugavyaghritagodhoomamaashakakandaphal aadikam." 45

Explaining the action of Vajikarana in different conditions Dalhana says that ${ }^{46}$ :

1) Alparetas- means persons having congenital deficiency of semen. Its treatment is Apyayana (Replenishing).

2) Dushtaretas- means those having semen affected by vitiated Doshas. Its treatment is Prasadana (Purification).

3) Kshinaretas- means those having acquired deficiency of semen. Its treatment is Upchaya (Increasing).
4) Vishushkaretas- means those having deficiency of semen below base-level. Its treatment is Janana (Producing).

Dalhana also gives alternative interpretations according to age such as ${ }^{46}$ -

1) Alparetas- below 25 years of age

2) Kshinaretas- Middle age

3) Vishuskaretas- Old age

\section{CONCLUSION}

Dalhana, because of his profound knowledge, long professional experience and field study, stands topmost among the commentators and his contribution particularly in the field of Dravyaguna are awesome and helpful for everyone. He is one of the commentators who have become immortal by his single but unique and extra-ordinary work. Dalhana's contribution to the ancient Indian system of medicine as the author of 'Nibandha Sangraha' is priceless. He has also evidently undertaken extensive tours throughout the country to get himself acquainted with the prevalent traditions and the systems of medicine. He was a versatile scholar and as such has contributed in discussing various allied topics which leads to clear understanding of the basic concepts. We can say that Dalhana's scholarship was not limited to Ayurveda only but covered a very wide field comprising of various disciplines which was necessary for proper understanding of Ayurvedic concepts.

\section{REFERENCES}

1. Sri Dalhana Acharya, Vaidya Jadvji Trikamji Acharya and Narayan Ram Acharya Kavyatirtha editor. Nibandha Sangraha commentary on Sushruta Samhita: Uttar Tantra 26/46, Shiroroga Pratishedha Adhyaya. Varanasi: Chaukhamba Sanskrit Sansthan; reprint 2014. P.659.

2. Sri Dalhana Acharya, Vaidya Jadvji Trikamji Acharya and Narayan Ram Acharya Kavyatirtha editor. Nibandha Sangraha commentary on Sushruta Samhita: Nidana sthana 16/66, Shiroroga Pratishedham Adhyaya. Varanasi: Chaukhamba Sanskrit Sansthan; reprint 2014. P.337.

3. Acharya P.V. Sharma. Dalhana and his comments on Drugs. New delhi: Munshiram Manoharlal Publishers Pvt. Ltd.; First edition 1982. P.4.

4. Sri Dalhana Acharya, Vaidya Jadvji Trikamji Acharya and Narayan Ram Acharya Kavyatirtha editor. Nibandha Sangraha commentary on Sushruta Samhita: Uttar Tantra 49/19, Chardi Pratishedham Adhyaya. Varanasi: Chaukhamba Sanskrit Sansthan; reprint 2014. P.756.

5. Sri Dalhana Acharya, Vaidya Jadvji Trikamji Acharya and Narayan Ram Acharya Kavyatirtha editor. Nibandha Sangraha commentary on Sushruta Samhita: Chikitsa sthana 28/27, Medha Ayushkamiya Rasayana Chikitsa Adhyaya. Varanasi: Chaukhamba Sanskrit Sansthan; reprint 2014. P.502.

6. Sri Dalhana Acharya, Vaidya Jadvji Trikamji Acharya and Narayan Ram Acharya Kavyatirtha editor. Nibandha Sangraha commentary on Sushruta Samhita: Uttar Tantra 65/34, Tantra Yuktima Adhyaya. Varanasi: Chaukhamba Sanskrit Sansthan; reprint 2014. P.818.

7. Sri Dalhana Acharya, Vaidya Jadvji Trikamji Acharya and Narayan Ram Acharya Kavyatirtha editor. Nibandha Sangraha commentary on Sushruta Samhita: Sutra sthana 46/187, Anna-pana Vidhi Adhyaya. Varanasi: Chaukhamba Sanskrit Sansthan; reprint 2014. P.228.

8. Sri Dalhana Acharya, Vaidya Jadvji Trikamji Acharya and Narayan Ram Acharya Kavyatirtha editor. Nibandha Sangraha commentary on Sushruta Samhita: Sutra sthana 
37/9, Mishraka Adhyaya. Varanasi: Chaukhamba Sanskrit Sansthan; reprint 2014. P.160.

9. Sri Dalhana Acharya, Vaidya Jadvji Trikamji Acharya and Narayan Ram Acharya Kavyatirtha editor. Nibandha Sangraha commentary on Sushruta Samhita: Chikitsa sthana 1/42, Dwi-vraniya Chikitsa Adhyaya. Varanasi: Chaukhamba Sanskrit Sansthan; reprint 2014. P.401.

10. Sri Dalhana Acharya, Vaidya Jadvji Trikamji Acharya and Narayan Ram Acharya Kavyatirtha editor. Nibandha Sangraha commentary on Sushruta Samhita: Sutra sthana 46/163, Anna-pana Vidhi Adhyaya. Varanasi: Chaukhamba Sanskrit Sansthan; reprint 2014. P.227.

11. Sri Dalhana Acharya, Vaidya Jadvji Trikamji Acharya and Narayan Ram Acharya Kavyatirtha editor. Nibandha Sangraha commentary on Sushruta Samhita: Chikitsa sthana 11/10, Prameha Chikitsa Adhyaya. Varanasi: Chaukhamba Sanskrit Sansthan; reprint 2014. P.453.

12. Sri Dalhana Acharya, Vaidya Jadvji Trikamji Acharya and Narayan Ram Acharya Kavyatirtha editor. Nibandha Sangraha commentary on Sushruta Samhita: Uttar Tantra 55/43, Udavrata pratishedham Adhyaya. Varanasi: Chaukhamba Sanskrit Sansthan; reprint 2014. P.780.

13. Dr. Brahmanand Tripathi. Charaka Samhita: Sutra Sthana 1/51, Dirghajivityam Adhyaya. Varanasi: Chaukhamba Surbharti Prakashan; reprint 2008. P.22.

14. Sri Dalhana Acharya, Vaidya Jadvji Trikamji Acharya and Narayan Ram Acharya Kavyatirtha editor. Nibandha Sangraha commentary on Sushruta Samhita: Sutra sthana 40/3, Dravya-Rasa-Guna-Virya-Vipaka Vigyaniyam Adhyaya. Varanasi: Chaukhamba Sanskrit Sansthan; reprint 2014. P.174.

15. .Sri Dalhana Acharya, Vaidya Jadvji Trikamji Acharya and Narayan Ram Acharya Kavyatirtha editor. Nibandha Sangraha commentary on Sushruta Samhita: Sutra sthana 40/1, Dravya-Rasa-Guna-Virya-Vipaka Vigyaniyam Adhyaya. Varanasi: Chaukhamba Sanskrit Sansthan; reprint 2014. P.173.

16. Dr. Brahmanand Tripathi. Charaka Samhita: Sutra Sthana 1/51, Dirghajivityam Adhyaya. Varanasi: Chaukhamba Surbharti Prakashan; reprint 2008. P.23.

17. Sri Dalhana Acharya, Vaidya Jadvji Trikamji Acharya and Narayan Ram Acharya Kavyatirtha editor. Nibandha Sangraha commentary on Sushruta Samhita: Sutra sthana 46/7, Anna-pana Vidhi Adhyaya. Varanasi: Chaukhamba Sanskrit Sansthan; reprint 2014. P.215.

18. Sri Dalhana Acharya, Vaidya Jadvji Trikamji Acharya and Narayan Ram Acharya Kavyatirtha editor. Nibandha Sangraha commentary on Sushruta Samhita: Sutra sthana 45/51, Drava-dravya Vidhi Adhyaya. Varanasi: Chaukhamba Sanskrit Sansthan; reprint 2014. P.201.

19. Sri Dalhana Acharya, Vaidya Jadvji Trikamji Acharya and Narayan Ram Acharya Kavyatirtha editor. Nibandha Sangraha commentary on Sushruta Samhita: Sutra sthana 41/4, Dravya Vishesha Vigyaniyam Adhyaya. Varanasi: Chaukhamba Sanskrit Sansthan; reprint 2014. P.182.

20. Sri Dalhana Acharya, Vaidya Jadvji Trikamji Acharya and Narayan Ram Acharya Kavyatirtha editor. Nibandha Sangraha commentary on Sushruta Samhita: Sutra sthana 45/112, Drava-dravya Vidhi Adhyaya. Varanasi: Chaukhamba Sanskrit Sansthan; reprint 2014. P.205.

21. Sri Dalhana Acharya, Vaidya Jadvji Trikamji Acharya and Narayan Ram Acharya Kavyatirtha editor. Nibandha Sangraha commentary on Sushruta Samhita: Sutra sthana 45/142, Drava-dravya Vidhi Adhyaya. Varanasi: Chaukhamba Sanskrit Sansthan; reprint 2014. P.208.

22. Sri Dalhana Acharya, Vaidya Jadvji Trikamji Acharya and Narayan Ram Acharya Kavyatirtha editor. Nibandha Sangraha commentary on Sushruta Samhita: Sutra sthana
41/5, Dravya Vishesha Vigyaniyam Adhyaya. Varanasi: Chaukhamba Sanskrit Sansthan; reprint 2014. P.182.

23. Sri Dalhana Acharya, Vaidya Jadvji Trikamji Acharya and Narayan Ram Acharya Kavyatirtha editor. Nibandha Sangraha commentary on Sushruta Samhita: Sharira sthana 1/19, Sarvabhoota Chinta Shariram Adhyaya. Varanasi: Chaukhamba Sanskrit Sansthan; reprint 2014. P.343.

24. Kaviraja Atrideva Gupta and Vaidya Yadunandan Upadhyaya. Ashtanga Hridaya: Sutra Sthana 9/20, Dravyadi Vigyaniyam Adhyaya. Varanasi: Chaukhamba Prakashan; reprint 2007. P.81.

25. Sri Dalhana Acharya, Vaidya Jadvji Trikamji Acharya and Narayan Ram Acharya Kavyatirtha editor. Nibandha Sangraha commentary on Sushruta Samhita: Sutra sthana 40/10, Dravya-Rasa-Guna-Virya-Vipaka Vigyaniyam Adhyaya. Varanasi: Chaukhamba Sanskrit Sansthan; reprint 2014. P.179.

26. Dr. Brahmanand Tripathi. Charaka Samhita: Sutra Sthana 26/13, Atreya-Bhadrakapiya Adhyaya. Varanasi: Chaukhamba Surbharti Prakashan; reprint 2008. P.472.

27. Sri Dalhana Acharya, Vaidya Jadvji Trikamji Acharya and Narayan Ram Acharya Kavyatirtha editor. Nibandha Sangraha commentary on Sushruta Samhita: Sutra sthana 45/11, Drava-dravya Vidhi Adhyaya. Varanasi: Chaukhamba Sanskrit Sans

28. than; reprint 2014. P.198.

29. Sri Dalhana Acharya, Vaidya Jadvji Trikamji Acharya and Narayan Ram Acharya Kavyatirtha editor. Nibandha Sangraha commentary on Sushruta Samhita: Sutra sthana 21/17, Vrana Prasanam Adhyaya. Varanasi: Chaukhamba Sanskrit Sansthan; reprint 2014. P.103.

30. Dr. Brahmanand Tripathi. Charaka Samhita: Sutra Sthana 26/67, Atreya-Bhadrakapiya Adhyaya. Varanasi: Chaukhamba Surbharti Prakashan; reprint 2008. P.489.

31. Sri Dalhana Acharya, Vaidya Jadvji Trikamji Acharya and Narayan Ram Acharya Kavyatirtha editor. Nibandha Sangraha commentary on Sushruta Samhita: Chikitsa sthana 33/33, Vamana-Virechana Sadhyoupdrava Chikitsitam Adhyaya. Varanasi: Chaukhamba Sanskrit Sansthan; reprint 2014. P.519.

32. Saini Malvika, Sharma Satyapal, Jaiswal Mohan Lal, Kotecha Mita. An Ayurveda approach to combat toxicity of chemo-radiotherapy in cancer patients. Int. J. Res. Ayurveda Pharm. Mar - Apr 2016;7(Suppl 2):124-129 http://dx.doi.org/10.7897/2277-4343.07271

33. Dr. Brahmanand Tripathi. Charaka Samhita: Sutra Sthana 1/52, Dirghajivityam Adhyaya. Varanasi: Chaukhamba Surbharti Prakashan; reprint 2008. P.24.

34. Sri Dalhana Acharya, Vaidya Jadvji Trikamji Acharya and Narayan Ram Acharya Kavyatirtha editor. Nibandha Sangraha commentary on Sushruta Samhita: Sutra sthana 38/9, Dravya sangrahaniyam Adhyaya. Varanasi: Chaukhamba Sanskrit Sansthan; reprint 2014. P.164.

35. Sri Dalhana Acharya, Vaidya Jadvji Trikamji Acharya and Narayan Ram Acharya Kavyatirtha editor. Nibandha Sangraha commentary on Sushruta Samhita: Sutra sthana 46/436, Anna-pana Vidhi Adhyaya. Varanasi: Chaukhamba Sanskrit Sansthan; reprint 2014. P.245.

36. Sri Dalhana Acharya, Vaidya Jadvji Trikamji Acharya and Narayan Ram Acharya Kavyatirtha editor. Nibandha Sangraha commentary on Sushruta Samhita: Sutra sthana 46/515, Anna-pana Vidhi Adhyaya. Varanasi: Chaukhamba Sanskrit Sansthan; reprint 2014. P.252.

37. Sri Dalhana Acharya, Vaidya Jadvji Trikamji Acharya and Narayan Ram Acharya Kavyatirtha editor. Nibandha Sangraha commentary on Sushruta Samhita: Sutra sthana 45/3, Drava-dravya Vidhi Adhyaya. Varanasi: Chaukhamba Sanskrit Sansthan; reprint 2014. P.196. 
38. Sri Dalhana Acharya, Vaidya Jadvji Trikamji Acharya and Narayan Ram Acharya Kavyatirtha editor. Nibandha Sangraha commentary on Sushruta Samhita: Sutra sthana 15/36, Dosha-Dhatu-Mala Kshaya Vriddhi Vigyaniya Adhyaya. Varanasi: Chaukhamba Sanskrit Sansthan; reprint 2014. P.74.

39. Sri Dalhana Acharya, Vaidya Jadvji Trikamji Acharya and Narayan Ram Acharya Kavyatirtha editor. Nibandha Sangraha commentary on Sushruta Samhita: Sutra sthana 46/438, Anna-pana Vidhi Adhyaya. Varanasi: Chaukhamba Sanskrit Sansthan; reprint 2014. P.246.

40. Sri Dalhana Acharya, Vaidya Jadvji Trikamji Acharya and Narayan Ram Acharya Kavyatirtha editor. Nibandha Sangraha commentary on Sushruta Samhita: Sutra sthana 46/522, Anna-pana Vidhi Adhyaya. Varanasi: Chaukhamba Sanskrit Sansthan; reprint 2014. P.252.

41. Sri Dalhana Acharya, Vaidya Jadvji Trikamji Acharya and Narayan Ram Acharya Kavyatirtha editor. Nibandha Sangraha commentary on Sushruta Samhita: Sutra sthana 46/360, Anna-pana Vidhi Adhyaya. Varanasi: Chaukhamba Sanskrit Sansthan; reprint 2014. P.240.

42. Sri Dalhana Acharya, Vaidya Jadvji Trikamji Acharya and Narayan Ram Acharya Kavyatirtha editor. Nibandha Sangraha commentary on Sushruta Samhita: Sutra sthana 1/7, Vedotpatti Adhyaya. Varanasi: Chaukhamba Sanskrit Sansthan; reprint 2014. P.3.

43. Sri Dalhana Acharya, Vaidya Jadvji Trikamji Acharya and Narayan Ram Acharya Kavyatirtha editor. Nibandha Sangraha commentary on Sushruta Samhita: Sutra sthana
1/8(7), Vedotpatti Adhyaya. Varanasi: Chaukhamba Sanskrit Sansthan; reprint 2014. P.3.

44. Acharya P.V. Sharma. Dalhana and his comments on Drugs. New delhi: Munshiram Manoharlal Publishers Pvt. Ltd.; First edition 1982. P.112.

45. Sri Dalhana Acharya, Vaidya Jadvji Trikamji Acharya and Narayan Ram Acharya Kavyatirtha editor. Nibandha Sangraha commentary on Sushruta Samhita: Sutra sthana 1/7, Vedotpatti Adhyaya. Varanasi: Chaukhamba Sanskrit Sansthan; reprint 2014. P.3.

46. Sri Dalhana Acharya, Vaidya Jadvji Trikamji Acharya and Narayan Ram Acharya Kavyatirtha editor. Nibandha Sangraha commentary on Sushruta Samhita: Chikitsa sthana 26/6, ksheena baliyam Vajikarana Chikitsitam Adhyaya. Varanasi: Chaukhamba Sanskrit Sansthan; reprint 2014. P.497.

47. Sri Dalhana Acharya, Vaidya Jadvji Trikamji Acharya and Narayan Ram Acharya Kavyatirtha editor. Nibandha Sangraha commentary on Sushruta Samhita: Sutra sthana 1/8(8), Vedotpatti Adhyaya. Varanasi: Chaukhamba Sanskrit Sansthan; reprint 2014. P.3.

\section{Cite this article as:}

Sharma Tarun, Ramamurthy A., Sharma Ravindra, Malviya Reeta. Dalhana and his contribution in Dravyaguna with special reference to fundamentals. Int. J. Res. Ayurveda Pharm. Jul Aug 2016;7(4):8-13 http://dx.doi.org/10.7897/22774343.074124

\section{Source of support: Nil, Conflict of interest: None Declared}

Disclaimer: IJRAP is solely owned by Moksha Publishing House - A non-profit publishing house, dedicated to publish quality research, while every effort has been taken to verify the accuracy of the content published in our Journal. IJRAP cannot accept any responsibility or liability for the site content and articles published. The views expressed in articles by our contributing authors are not necessarily those of IJRAP editor or editorial board members. 